\title{
PROTECTION OF THE SZACHOWNICA CAVE AS AN EXAMPLE OF SAVING A VALUABLE BAT WINTERING SHELTER
}

\author{
Maurycy Ignaczak ${ }^{1}$, Tomasz Postawa ${ }^{2}$ \\ ${ }^{1}$ Polish Society for Bats Protection, \\ Baczyńskiego 6/13, 98-220 Zduńska Wola, Poland \\ e-mail:imoris@ksiezyc.pl \\ ${ }^{2}$ Institute of Systematics and Evolution of Animals, Polish Academy of Sciences \\ 31-016 Kraków, ul. Stawkowska 17 \\ e-mail:tpostawa@gmail.com
}

\begin{abstract}
Protection of the Szachownica cave as an example of saving a valuable bat wintering shelter. Ignaczak, M., Postawa, T. - The Szachownica cave (Kraków-Wieluń Upland, Poland) is one of the four largest wintering shelters for bats in Poland. Since the cessation of limestone mining, the number of wintering bats increased from 300 to more than 2,900 individuals. In recent years, there has been seen a gradual worsening of the cave structure due to frost destruction, which leads to the possible disintegration of a major part of the cave. To prevent damage of the cave the mining methods were used, because they can i) restrict access to the bats shelters, and ii) change microclimate. Monitoring of the abundance of bats was carried out twice during a winter: in end of January and in March. The temperature was measured in 3 points in the cave and in 1 outside. Securing the cave: i) only in minor degree changed the temperature amplitude, but not the mean temperature, whereas penetration of water (and also frost damage) was limited, ii) did not change either the species composition or species-specific long-term trends in the amount of bats hibernating in the cave. However, to assess fully the impact of changes, monitoring of both the bat fauna and microclimate will be continued during the next several years.
\end{abstract}

Key words: bats, hibernation, microclimate, protection, Szachownica cave.

Захист печери «Шаховниця» як приклад збереження цінного для кажанів зимівельного притулку. - Ігначак, М., Постава, Т. - Печера «Шаховниця» (Краківсько-Велюнська височина, Польща) $є$ одним із чотирьох найбільших зимівельних сховищ кажанів у Польщі. Після припинення видобутку вапняку, кількість зимуючих тут кажанів зросла із 300 до понад 2900 особин. За останні роки спостерігається поступове погіршення структури печери через морози, що може призвести до обвалу значної iї частини. Аби запобігти пошкодженню печери, було застосовано гірничі методи, що можуть 1) обмежити доступ кажанів до сховища та 2) змінити його мікроклімат. Моніторинг чисельності кажанів здійснено двічі за зиму: в кінці січня та у березні. Вимірювання температури проведено у трьох точках печери та в одній точці за ії межами. Укріплення печери 1) незначно вплинуло на коливання температури, але не на іï середній показник, обмежило проникнення води (а також морозне руйнування), i 2) не вплинуло на видовий склад або видоспецифічні довгострокові тенденції змін чисельності зимуючих в печері кажанів. Однак, для повної оцінки впливу змін, моніторинг хіроптерофауни та мікроклімату буде продовжуватися протягом наступних кілька років.

Ключові слова: кажани, гібернація, мікроклімат, охорона, печера «Шаховниця».

\section{Introduction}

Large underground systems with differential microclimate are important locations for hibernation of bats (Mitchell-Jones, 2016). However, their availability is restricted mainly to the karstic regions, while in areas without natural caves usually man-made undergrounds such as fortifications (fortress, bunkers) (Hutson et al., 2001), cellars, or even water wells (Ignaczak, 2009) provide hibernating places. Natural caves, either karstic or tectonic, might be stable even for thousands of years, as it's evidenced by the accumulated sediments containing animal bone remains (Wołoszyn, 1988). 
Man-made or natural undergrounds changed due to human activity can be much less stable, threatened by destruction because of erosion of the stability of the rock mass or other random reasons. The disintegration of such important shelters can result in long-term and irreversible changes in the bat fauna, not only in a local scale, but also over a large area (Furey, Racey, 2016).

In Poland, the first three largest winter shelters for bats are man-made: fortification (MRU Cichocki et al., 2015), Baszta Michałowska (Lesiński et al., 2008), and drainage systems in Olsztyn (Wojtaszyn et al., 2013). This wintering site is located more than $250 \mathrm{~km}$ far from the nearest natural undergrounds. The forth in the number of wintering bats is the Szachownica cave (central Poland, Kraków-Wieluń Upland), a large karstic underground system, partially changed during limestone exploitation (Ignaczak, Lesiński, 2012).

Since the cessation of limestone mining, the number of wintering bats increased from approx. 300 individuals (in 1982) to more than 2,900 individuals of 11 bat species during recent years (Lesiński et al., 2011). The Szachownica cave comprise a wintering place both for migratory bat species for medium distances: $M$. myotis, $M$. nattereri, and sedentary species as well: B. barbastellus. Constant increases in the number of wintering bats were reported, especially for the most abundant species, which is associated with both the general trends in populations and the appearance of animals from new areas (Lesiński et al., 2011). Typical for this cave is a very diverse microclimate and a large number of crevices providing a hideout for many bat species, e.g. for the rare $M$. bechsteinii (up to 50 ind.) or $M$. dasycneme (up to 10 ind.). The cave and its surroundings are also a place of mass autumn activity of bats, where during one night were caught up to 900 ind. belonging to 10 bat species, making it the largest swarming site in Poland (Ignaczak, Lesiński, 2012). Since 2007, the natural reserve "Szachownica cave" is included into the Natura2000 net as a "Special area of conservation Szachownica PLH240004".

Underground excavations of limestone changed the shape of this cave and caused a significant violation in its microclimate (Głazek et al., 1978). In recent years, there has been a gradual worsening caused by frost destruction, which leads to the possibility of the destruction of a major part of the cave (Polonius 2001), including wintering locations, mainly of B. barbastellus and P. auritus. To prevent the damage of such a valuable wintering place, the Regional Directorate for Environment Protection in Katowice decided to protect the ceiling using methods of the mining industry (LIFE12 NAT/PL/000012). Since the mining methods can i) restrict access to the bats shelters (crevices), and ii) change the microclimate, we have conducted a complex monitoring of both the bat fauna and microclimate changes before, during and after the securing works.

\section{Material and methods}

\section{Study area}

The natural reserve "Szachownica cave" (18 $\left.48^{\prime} 39^{\prime \prime} \mathrm{E}, 51^{\circ} 03^{\prime} 22^{\prime \prime} \mathrm{N}\right)$ is situated in the middle of the Wielun Upland, which is the northern part of Kraków-Wielun Upland (central Poland). It includes a wooded limestone hill Krzemienna Góra $(224 \mathrm{~m})$ with an area of 12.70 ha, together with an extensive cave split by a quarry during the limestone excavation: Szachownica I with a length of about $700 \mathrm{~m}$, Szachownica II with a length of about $200 \mathrm{~m}$, and Szachownica III-V — small fragments in the southern part of the quarry (Górny, Szelerewicz, 2010).

The exploitation of limestone was ceased in 1962. Because of mining and underground excavation of limestone, natural corridors were artificially widened to the size of large chambers. Currently in Szachownica I, the amount of natural parts is about $40 \%$ of the total length.

To protect this unique geological object, a proglacial cave - special genetic types of cave in glaciated areas, in 1978 a geological reserve was established. The first notice about mass wintering of bats comes from the report "Project of the geological reserve Szachownica" (Bednarek et al., 1977). Regular monitoring of bats hibernating in this cave started at the beginning of the 1980s and it is preceded until today. Monitoring of the numbers of bats was carried out twice during the winter: in end of January and in March, due to the large differences in species composition between the be- 
ginning and the end of winter. Among wintering species the most abundant are M. nattereri (1201 ind.), B. barbastellus (992 ind.), M. myotis (670 ind.), P. auritus (378 ind.), while M. daubentonii (212 ind.) and M. mystacinus/brandtii (108 ind.) are the less abundant ones. The other bat species hibernate in small numbers (Hejduk, Radzicki, 1996; Ignaczak, Lesiński, 2012).

Preliminary studies of the cave's microclimate (temperature and humidity) were conducted by Hejduk and Radzicki (1996), but, as in this case and later studies, the measurements were performed at a height of $1.5 \mathrm{~m}$ above the cave floor. Temperature variations in the natural corridors were much lower than in the corridors artificially extended, however this variation is significant and the cave is considered as underground with dynamic microclimate (Głazek et al., 1978; Polonius, 2001).

The first plan for the protection of the Szachownica cave from collapsing was prepared in 1996, but it has been never implemented. During the following years the "Critical revision of the ability to protect the cave" (2001) and "Habitat Restoration Management Plan" (2007) were prepared too. In 2015, the operation for protection of the cave was started, and it was divided into 2 stages: i) 3.0721.09.2015 — the main work with securing of the ceiling of the cave, and ii) 8.06-23.09.2016 finishing the works. All securing works were carried out during off-season of bats hibernation. During the summer, the work was carried out only in daylight to minimize the impact on either the feeding activity or swarming of bats. The caves were secured by: i) anchoring the floor - the strengthening of the rock mass ( $>230$ anchors) and securing the metal mesh $\left(453 \mathrm{~m}^{2}\right.$ metal wire mesh) were made; ii) injection of glue (bonding rock layers and cutting off of water from the surface) - 74.5 tons of non-toxic mineral and organic glue were used; iii) construction of pillars to underpin the roof -3 pillars were built.

\section{Temperature}

Both for bats and to assess the degree of destruction of the roof of the cave it is important to check the conditions in places of bats hibernation. Data loggers (DS1923 Thermochron iButton, Maxim Integrated Products, USA, accuracy $0.5^{\circ} \mathrm{C}$, resolution $0.5^{\circ} \mathrm{C}$ ) were placed in three locations in the cave: Złomisk hall (logger 1), Przejściowa hall (logger 2), Równoległy passage (logger 3), and one was placed outside the cave to measure the outside temperature (logger 4 ). The temperature was recorded with 2-h intervals throughout the study. Measurements were taken during three winter seasons: 2009/10 (before cave protection), 2014/15 (the beginning of the safety work), and 2015/16 (after the completed work). Two parameters were counted: i) amplitude - due to different influence of weather condition/outside on different part of cave, ii) minimum daily temperature, due to its effect on frost weathering.

Moreover, weather parameters such as minimal temperature $\left({ }^{\circ} \mathrm{C}\right)$, precipitation $(\mathrm{mm})$ and snow cover $(\mathrm{cm})$, were used from the nearest meteorological station's data (Pyrzowice).

\section{Bats}

Bat census was carried out twice during the hibernation period: at the end of January and at the beginning of March (highest abundance of hibernating bats). To compare data with microclimate monitoring we used monitoring data from consecutive years: 2009/10: 31.01 .2010 and 07.03.2010; 2014/15: 31.01.2015 and 07.03.2015; 2015/16: 30.01 .2016 and 05.03.2016. Counts were preformed without removing bats from the roost's walls. Bats were found using LED headlamps, determination were performed according to species-specific features. Single individuals and small clusters were directly counted, larger clusters were photographed using a digital camera and the bats were counted from photos. Most of the inhabited parts of the cave by the most abundant species were placed on the cave's scheme to evaluate the importance of each part of the Szachownica cave (fig. 1).

\section{Statistics}

To evaluate differences between microclimate characters two-way ANOVA-s were used with Tukey-Kramer post-hoc test. A significance criterion of $\mathrm{P}<0.05$ was used for all statistical tests. Results are reported as mean $\pm \mathrm{SD}$.

Statistical analyses were performed by using STATISTICA 6.0. 


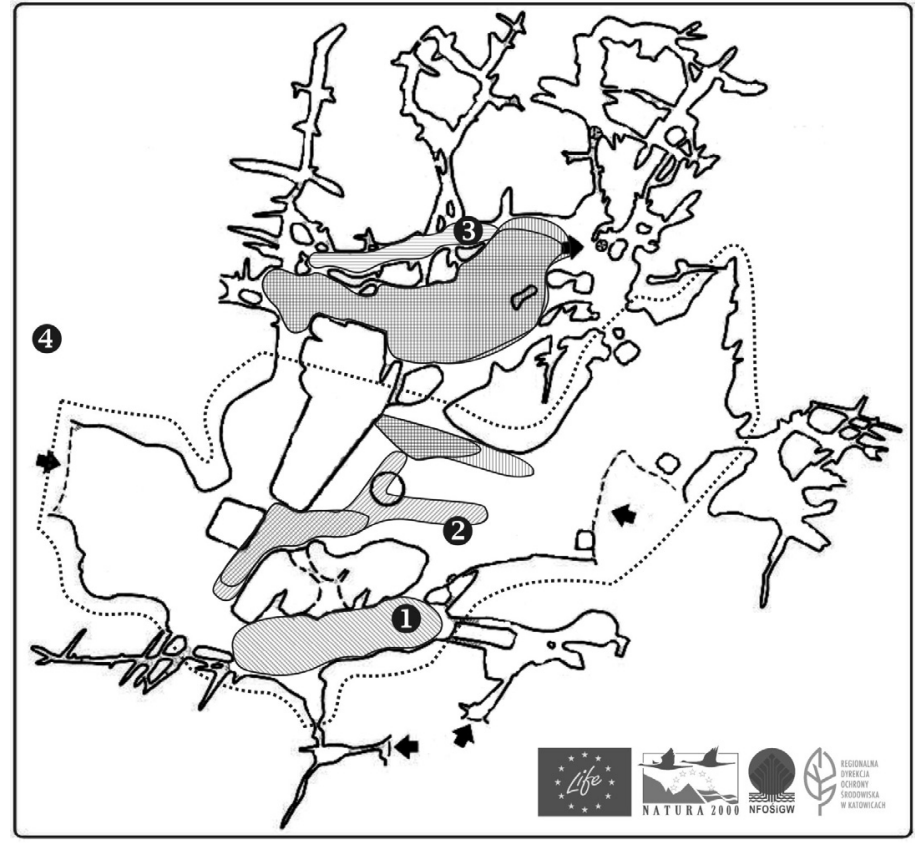

B. barbastellus $\amalg$ M. myotis $\mathbb{N}$ P. auritus M. nattereri
Fig. 1. The scheme of the Szachownica cave (after: Zygmunt, 2016).

Arrows - entrances, dashed line - the area with dynamic microclimate and under the threat of collapse.

Location of loggers: 1 - Złomisk hall, 2 Przejściowa hall, 3 - Równoległy passage, 4 - logger outside. Shaded area place with the highest number of wintering bats.

Рис. 1. Схема печери «Шаховниця» (за: Zygmunt, 2016).

Стрілки показують входи, переривчаста лінія - територія 3 динамічним мікрокліматом та під загрозою обвалу.

Розташування реєстраторів температури: 1 - зала «Зломіск», 2 - зала «Пшейщова», 3 - прохід «Ровнолеглий», 4 реєстратор поза печерою. Заливка позначає місця найбільшого скупчення зимуючих кажанів.

\section{Results}

\section{Weather conditions}

Over the 3 winter seasons, differences were noted in the minimal daily temperature and snow cover, but not in precipitation. The lowest mean temperatures were recorded in the season 2009/10, while the remaining hibernation seasons $(2014 / 15$ and $2015 / 16)$ had similar mean temperatures (fig. 2). Snow cover was the largest in 2009/10, less in 2014/15, and the smaller in 2015/16 (all differences significant). In turn, the precipitation over those three seasons was similar with no significant differences (tab. 1).

\section{Cave ambient temperature}

Mean daily amplitude of temperatures prevailing outside the cave entrance did not differ significantly between seasons (logger $4: \mathrm{F}=0.48, \mathrm{p}=0.62$ ), just as in the Równoległy passage - these are parts of static microclimate $(\operatorname{logger} 3: \mathrm{F}=1.14, \mathrm{p}=0.323)$. Significant differences were found in Złomisk hall (logger 1: $\mathrm{F}=8.61, \mathrm{p}=0.0002$ ) and in Przejściowa hall (logger 2: $\mathrm{F}=14.8$, $\mathrm{p}<0.0001$ ). In Złomisk hall, the daily amplitude was significantly higher in $2015 / 16$ than during $2009 / 10(p=0.004)$ and $2014 / 15(p=0.0003)$ seasons, while seasons $2009 / 10$ and $2014 / 15$ were similar (0.737). In turn, in Przejściowa hall, the daily amplitude from 2015/16 was significantly lower than during previous years, both from 2009/10 $(p<0.0001)$ and 2014/15 $(p<0.0001)$. The seasons $2009 / 10$ and $2014 / 15$ did not differ in mean daily amplitude $(p=0.999)$. In the stable part of the cave, the Równoległy passage, the daily amplitude did not differ between all seasons.

Minimum daily temperatures were significantly different between the seasons in each location (tab. 1). The lowest mean temperature outside the cave was noted in season 2009/10 and was lower from both 2014/15 ( $p<0.0001)$ and 2015/16 ( $<<0.0001$ ). In turn, 2014/15 and 2015/16 had similar mean temperature $(p<0.0001)$. In Złomisk hall, the highest temperature was noted in $2014 / 15$ and it was significantly higher than in 2009/10 ( $p<0.0001)$ and 2015/16 $(\mathrm{p}<0.0001)$. In turn, in Przejściowa hall, the lowest minimal temperatures were noted in $2009 / 10$, following by higher in 2014/15, and the highest in 2015/16 with significant differences from all seasons.

A similar pattern was noted for the Równoległy passage (tab. 1). 
Table 1. Results from ANOVA analyses to compare weather conditions outside of the cave (a) with the temperature prevailing in the Szachownica cave (b). Logger 1 - Złomisk hall, logger 2 - Przejściowa hall, logger 3 Równoległy passage (location marked on fig. 1)

Таблиця 1. Результати дисперсійного аналізу для порівняння погодних умов поза печерою (а) 3 температурою, що панує в печері «Шаховниця» (b). Реєстратор 1 - зала «Зломіск», реєстратор 2 - зала «Пшейщова», реєстратор 3 - прохід «Ровнолеглий» (розташування точок позначено на рис. 1)

\begin{tabular}{l|c|c|c|c|cc}
\hline $\begin{array}{l}\text { Microclimate } \\
\text { parameters }\end{array}$ & d.f. & $\begin{array}{c}2009 / 2010 \\
\text { aver } \pm \mathrm{SD}\end{array}$ & $\begin{array}{c}2014 / 15 \\
\text { aver } \pm \mathrm{SD}\end{array}$ & $\begin{array}{c}2015 / 16 \\
\text { aver } \pm \mathrm{SD}\end{array}$ & $\mathrm{F}$ & $\mathrm{p}$ \\
\hline a) outside of the cave & & & & & & \\
minimum temperature $\left[{ }^{\circ} \mathrm{C}\right]$ & $2 ; 267$ & $-5,62 \pm 5,530$ & $-2,68 \pm 3,796$ & $-2,03 \pm 5,228$ & 13,6 & $<0,00001 * * *$ \\
precipitation [mm] & $2 ; 196$ & $1,57 \pm 2,487$ & $1,52 \pm 2,934$ & $2,26 \pm 3,496$ & 1,26 & $0,285321 \mathrm{~ns}$ \\
snow [cm] & $2 ; 135$ & $14,81 \pm 10,520$ & $6,97 \pm 4,816$ & $1,93 \pm 2,154$ & 29,8 & $<0,00001 * * *$ \\
b) in the Szachownica cave & $2 ; 286$ & & & & & \\
temperature amplitude $\left[{ }^{\circ} \mathrm{C}\right]$ & outside $(4)$ & $5,6 \pm 4,25$ & $5,2 \pm 3,58$ & $5,1 \pm 2,85$ & 0,48 & $0,6186 \mathrm{~ns}$ \\
& Logger 1 & $0,23 \pm 0,298$ & $0,26 \pm 0,159$ & $0,39 \pm 0,345$ & 8,61 & $0,0002 * * *$ \\
& Logger 2 & $0,94 \pm 0,758$ & $0,94 \pm 0,922$ & $0,44 \pm 0,420$ & 14,8 & $<0,00001 * * *$ \\
& Logger 3 & $0,09 \pm 0,196$ & $0,06 \pm 0,085$ & $0,09 \pm 0,192$ & 1,14 & $0,3225 \mathrm{~ns}$ \\
temperature minimum $\left[{ }^{\circ} \mathrm{C}\right]$ & outside $(4)$ & $-4,06 \pm 5,736$ & $-0,22 \pm 3,397$ & $-0,19 \pm 4,848$ & 21,0 & $<0,00001 * * *$ \\
& Logger 1 & $1,65 \pm 0,909$ & $3,50 \pm 0,613$ & $3,29 \pm 0,920$ & 144,2 & $<0,00001 * * *$ \\
& Logger 2 & $-0,46 \pm 2,762$ & $2,69 \pm 1,032$ & $3,61 \pm 1,117$ & 131,8 & $<0,00001 * * *$ \\
& Logger 3 & $2,71 \pm 0,848$ & $5,35 \pm 0,392$ & $5,91 \pm 0,620$ & 671,1 & $<0,00001 * * *$ \\
\hline
\end{tabular}

\section{Bats monitoring}

The total number of bats wintering in the Szachownica cave ranged from 1235 in January and 1820 in March 2009/10, followed by 2173 and 2334 in 2014/15 to 2280 and 2534 individuals in 2015/16. For the two most numerous bat species, M. myotis and M. nattereri, a constant trend of growth in number during both counts in January and March was recorded. For other species, however, in both terms of counts significant fluctuations of abundance were observed, with the greatest differences noted for B. barbastellus and P. auritus, while differences for M. mystacinus/brandtii and M. daubentonii were smaller (fig. 3).

The increase of the number of M. myotis between season $2009 / 10$ and $2014 / 15$ was $56 \%$ for January counting and $41 \%$ for March counting, and between seasons 2014/15 and 2015/16 was similar for both counts amounted $19 \%$ and $20 \%$ respectively. A similar pattern was observed for M. nattereri, where between season 2009/10 and 2014/15 the abundance of this species has increased to a similar extent both for January counts (11\%) and March counts (15\%), while between season 2014/15 and 2015/16 the increase of abundance was twice higher for January monitoring $(32 \%)$ than for March monitoring (16\%).

Other species showed different trends depending on the date of the winter counts. B. barbastellus between season 2009/10 and 2014/15 showed a $65 \%$ increase in number for the January count and only $10 \%$ for the March visit, and between winter 2014/15 and 2015/16 a similar decline (48 \% and $38 \%$ ) were noted for both counts. On the other hand, between winter 2009/10 and 2015/16, there was a $34 \%$ increase in number for the January counts, and a $47 \%$ decline for the March counts. In turn, $P$. auritus between season 2009/10 and 2014/15 showed a $46 \%$ increase in number for the January count, and a $82 \%$ decrease in March, while between winter 2014/15 and 2015/16 $57 \%$ and $13 \%$ declines were noted, respectively. On the other hand, between winters 2009/10 and $2015 / 16$ there was a $16 \%$ increase in the number of bats in January, while a $52 \%$ decline was noted for the March counts. For a pair of hardly distinguishable species: M. mystacinus/brandtii, between season 2009/10 and 2014/15 there was a similar increase in number for January $(50 \%)$ and for March counting's (57\%), and between winter 2014/15 and 2015/16 for January a slight increase in number (3\%) was recorded, while in March a slight decline (8\%). For M. daubentonii, between winter 2009/10 and 2014/15 a $12 \%$ decline for the January counting was noted, while a $43 \%$ in- 
crease in number of was found for March monitoring. Between seasons 2014/15 and 2015/16, a $5 \%$ decline in number was noted in January, and a $29 \%$ decline during March counting.

\section{Discussion}

\section{Microclimate}

The temperature in the dynamic parts of the Szachownica cave differs between seasons and in significantly correlated with the outdoor conditions. However, our results in some degree differ from the previous observations. The amplitude of temperature recorded under the ceiling of the cave, besides the vicinity of the entrance openings, and in the Złomisk hall, and in the Przejściowa hall, is characterized by small amplitudes and significantly differs from previous microclimatic cave characteristics (Głazek et al., 1978; Polonius, 2001). Differences in the range of climatic zones are the result of the use of measurements of microclimate parameters at different heights - they were usually made 0.5 to $1.5 \mathrm{~m}$ high above the floor (Piasecki, Kwiatkowski, 1989).

The temperature at bat wintering shelters (crevices) however, is much more modeled by the rock temperature than by air circulation (Postawa, 2000; authors' data). This is evident for wintering species in hidden places and tolerant to significant wintering temperature fluctuations, for which the termopreferendum is given from $-2^{\circ} \mathrm{C}$ for $P$. auritus (Nagel, Nagel, 1991) and from $-3{ }^{\circ} \mathrm{C}$ for B. barbastellus (Bogdanowicz, Urbańczyk, 1983; Harmata, 1973).

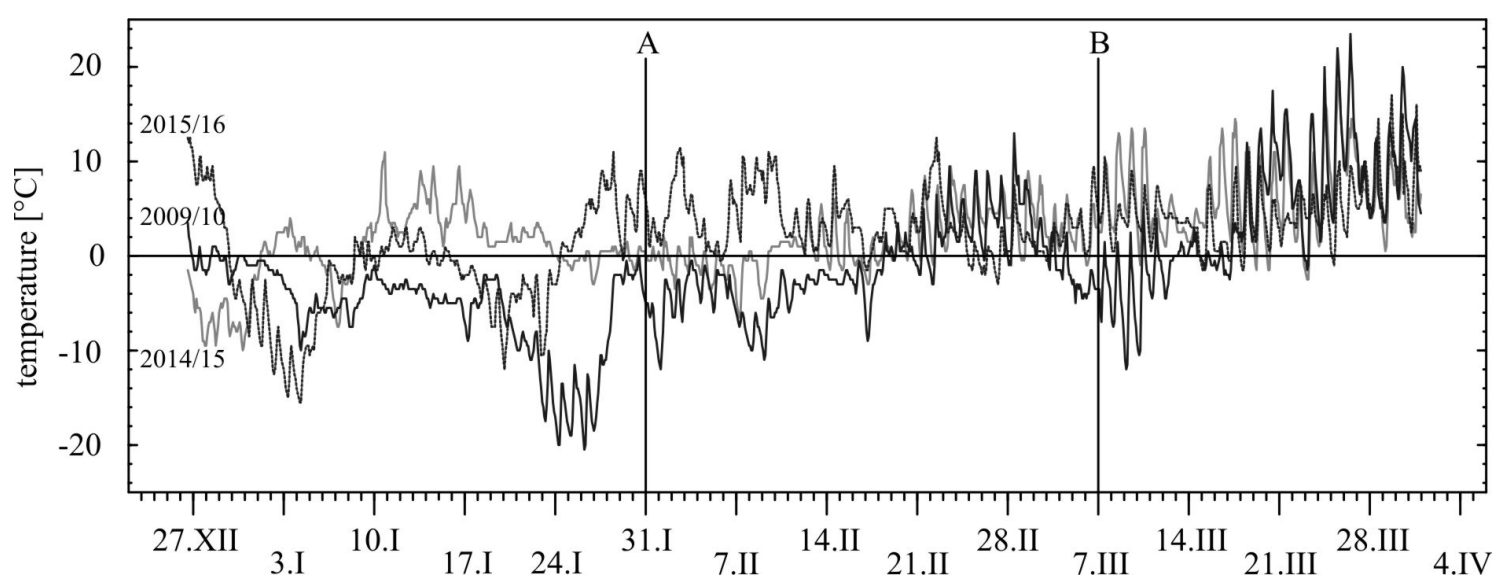

Fig. 2. Two hourly recordings of temperature on data logger (logger 4) at the main entrance of the Szachownica cave during three winters: 2009/10, 2014/15 and 2015/16. A - monitoring at the end of January, B - monitoring at the beginning of March.

Рис. 2. Двогодинні записи температури на реєстраторі (реєстратор 4) біля головного входу печери «Шаховниця» протягом трьох зим: 2009/10, 2014/15, 2015/16. А — моніторинг в кінці січня, В — моніторинг на початку березня.

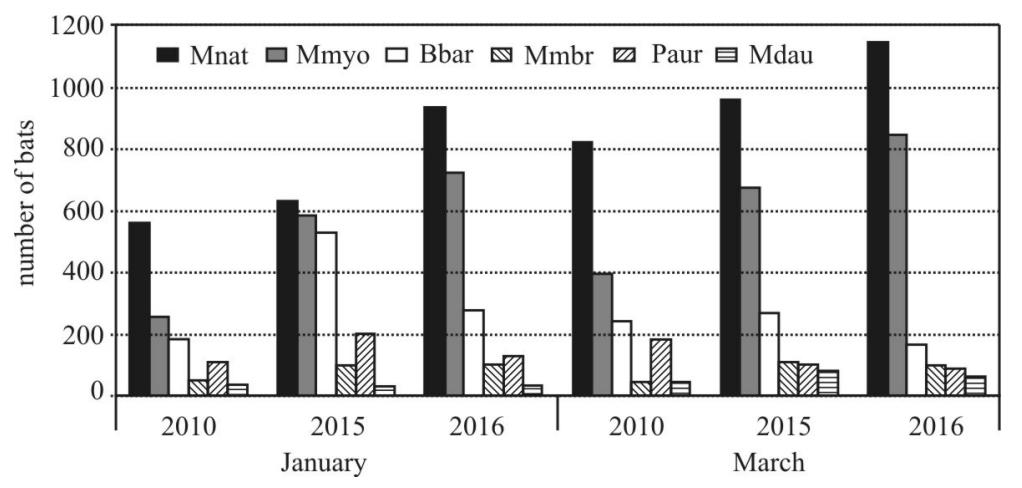

Fig. 3. Results of bat censuses in the Szachownica cave during three years of research.

Рис. 3. Результати обліку кажанів у печері «Шаховниця» протягом трьох років дослідження.

Mnat - M. nattereri,

Mmyo - M. myotis,

Bbar - B. barbastellus,

Mmbr - M. mystacinus/brandtii,

Paur-P. auritus,

Mdau - M. daubentonii. 
In contradiction to the previous research, in spite of strong frosts in 2009/10 we did not notice the temperature below $0^{\circ} \mathrm{C}$ in the Złomisk hall (the main wintering location of $P$. auritus), whereas in the Przejściowa hall such readings were only $10 \%$ (the main wintering location of $B$. barbastellus). In the last two winters, we did not recorded temperatures below $0^{\circ} \mathrm{C}$ for both measuring points. Therefore, in order to characterize fully the microclimate and to reflect the vertical stratification of the temperature, measurements should be made not only at the level of the floor or up to $1.5 \mathrm{~m}$ above it, but also under the ceiling.

The microclimate of an underground is determined by several parameters such as length, number of entrances, local habitat (Perry, 2013), and the change of one of them can change the range of the particular zones, and as a result - affect the fauna of wintering there bats.

As a result of the protection work carried out - the construction of an additional pillar in the central part of the Przejściowa hall, the air circulation has changed in a certain degree. This is evidenced by the higher amplitude of the temperature in the Złomisk hall and smaller in the Przejściowa hall; such differences in turn were not observed in the static parts. In spite of these differences, however, there were no changes in the preferences of bat wintering sites within the cave. Moreover, an additional effect of preventing water penetration from the surface inside the cave is the absence of ice formation in the central part of the Przejściowa hall, which, in turn, caused mortality of $B$. barbastellus and $P$. auritus even in mild winters (authors' data).

\section{Bats}

The increase in bat abundance was recorded for the two most numerous species, preferring the static microclimate: M. myotis and M. nattereri. Continuous increase in both species has been recorded since 2000, with relatively large fluctuations both between and within the years (Lesiński et al., 2011). Minor differences in rates of increase were noted for the pairs of sibling species: M. mystacinus/brandtii - similar to M. myotis and M. nattereri, these two species in the Szachownica cave usually hibernated in the zone of static microclimate. Therefore, potential impact of cave ceiling protection for these species is rather insufficient. In turn for B. barbastellus and P. auritus species preferring dynamic parts of the cave during hibernation, in the winter 2015/16 (after the carried work) were noted less abundant than in the previous winter but higher than in 2009/10. Both species are characterized by significant fluctuations in abundance both between seasons and within the same seasons - up to several hundred of percents (Lesiński et al., 2011). Differences in numbers may be the result of: i) population changes, ii) microclimate differences between the years (winter effect), and iii) cave protection effect (last season). In long-term monitoring - over 30 years, provided in the Szachownica cave, the beginning of the increase of bats abundance was slight, but since 2000 the increasing tendency seems to be faster for M. myotis, M. nattereri, M. brandtii/mystacinus, B. barbastellus and P. auritus but not for M. daubentonii (Lesiński et al., 2011; Ignaczak, Lesiński, 2012). These trends could be partly explained by the colonization by bats of a new winter roost, however in other large winter shelters we noted similar rate of increase (Fuszara et al., 2010) and not only in Poland (Uhrin et al., 2010; Haysom et al., 2014; Van der Meij et al., 2015).

The abundance of all numerous wintering bat species however is subjected to considerable fluctuations. It is larger in species with a broader thermopreferendum: B. barbastellus and P. auritus, and smaller in species wintering under stable conditions: M. myotis, M. nattereri, M. brandtii/mystacinus and M. daubentonii (Lesiński, 1986; Nagel, Nagel, 1991; Postawa, 2000). The reason for the differences in the number of bats both between seasons and within the season appears to be the conditions outside the cave; however, their impact seems to be species-specific. The largest fluctuation was noted in sedentary bat species, but with wider toleration for temperature amplitude. These two species can use less isolated shelters during warmer days in winter and more hidden during heavy frosts (Harmata, 1973; Lesiński, 1986). In turn, species that hibernate in static zones (with slight annual amplitude of temperature) migrated to the Szachownica cave from a distance even $90 \mathrm{~km}$ far (Wojtaszyn et al., 2010). It is possible that fluctuation in bats abundance between seasons may be caused by climatic variations during migration from breeding/swarming sites to wintering places; however, this hypothesis requires additional research. 
Finally, the potential cause for the lower abundance of B. barbastellus and $P$. auritus could be the effect of microclimate changes due to ceiling protection. However, this hypothesis seems to be the least possible - until now in both the abundance and distribution of wintering species in the Szachownica cave greater variations were noted (Ignaczak, Lesiński, 2012).

To assess fully the impact of changes, monitoring of bat fauna and microclimate will be continued during the next several years, with detailed analyses of the influence of weather factors such as the rain, snow, and temperature below $0^{\circ} \mathrm{C}$.

\section{Acknowledgments}

This research was supported by the project LIFE12 NAT/PL/000012: "Carrying out necessary conservation work on a territory of Szachownica designated Natura 2000". The project is cofinanced with the European Union funds under the financial instrument LIFE+ and the National Fund for Environmental Protection and Water Management. Co-ordinating beneficiary: Regional Directorate for Environmental Protection in Katowice, Poland.

\section{References}

Bednarek, J., Gtazek, J., Rudnicki, J. et al. Projekt rezerwatu geologicznego "Szachownica". Warszawa, Wrocław, 1977. P. 1-23. (Manuscript).

Bogdanowicz, W., Urbańczyk, Z. Some ecological aspects of bats hibernating in city of Poznan // Acta Theriologica. 1983. Vol. 28 (24). P. 371-385.

Cichocki, J., Stopczyński, M., Bator, A. et al. Liczebność nietoperzy zimujących w rezerwacie Nietoperek w roku 2015 // Streszczenia XXIV Ogólnopolskiej Konferencji Chiropterologicznej, 13-15.11.2015. Kazimierz Dolny, 2015. P. 36-37.

Fuszara, E., Fuszara, M., Kowalski, M. et al. Population changes in Natterer's bat Myotis nattereri and Daubenton's bat M. daubentonii in winter roosts of central Poland // Polish Journal of Ecology. 2010. Vol. 58 (4). P. 769-781.

Furey, N., Racey, P. Conservation Ecology of Cave Bats // Voigt, C., Kingston, T. (ed.). Bats in the Anthropocene: Conservation of bats in a changing world. Chapter: Conservation ecology of cave bats. Springer, 2016. P. 463-500.

Glazek, J., Bednarek, J., Szynkiewicz, A., Wierzbowski, A. Geneza jaskini Szachownica największego systemu jaskiniowego Wyżyny Krakowsko-Wieluńskiej // Kras i Speleologia. 1978. Vol. 2. P. 38-50.

Górny, A., Szelerewicz, M. Jaskinie Wyżyny Wieluńskiej / Ed. by J. Grodzicki. Wyd. Polskie Tow. Przyj. Nauk o Ziemi. Warszawa, 2010. $136 \mathrm{p}$.

Haysom, K. A., Dekker, J., Russ, J. et al. European bat population trends. A prototype biodiversity indicator. 2014. European Environment Agency Technical Report No 19/2013.

Harmata, $W$. The thermopreferendum of some species of bats (Chiroptera) in natural conditions // Zeszyty Naukowe UJ., 332, Pr. zool. 1973. Vol. 19. P. 127-141.

Hejduk, J., Radzicki, G. Changes in numbers of bats hibernating in the "Szachownica" cave (during season 1993/94 and 1994/95) // B. W. Wołoszyn (ed.). The actual problems of bat protection in Poland / Publication of Chiropterological Information Center, ISEZ PAN. Kraków, 1996. P. 41-55.

Hutson, A. M., Mlckleburgh, S. P., Racey, P. A. Microchiropteran Bats. Global Status Survey and Conservation Action Plan. IUCN/SSC Chiroptera Specialist Group. Gland, Switzerland and Cambridge, 2001. $258 \mathrm{p}$.

Ignaczak, M. Przydomowe studnie jako schronienia zimowe nietoperzy w Środkowej Polsce // Nietoperze. 2009. Vol. 10 (1-2). P. 37-46.

Ignaczak, M., Lesiński, G. Nietoperze Jaskini Szachownica w Załęczańskim Parku Krajobrazowym 30 lat badań (19812010). Studiokoloru, Warszawa, 2012. 36 p.

Lesiński, G. Ecology of bats hibernating underground in central Poland // Acta Theriologica. 1986. Vol. 31. P. 507-521.

Lesiński, G., Olszewski A., Filewicz M. The largest bat hibernaculum in the Mazovia region // Nietoperze. 2008. Vol. 9. P. 59-63.

Lesiński, G., Ignaczak, M., Kowalski, M. Increasing bat abundance in a major winter roost in central Poland over 30 years // Mammalia. 2011. Vol. 75. P. 163-167.

Mitchell-Jones, $T$. Conservation of Key Underground sites: the database. "Transboundary programme habitats: Data compilation". 2016. https://goo.gl/N6w1CA

Nagel, A., Nagel, R. How do bats choose optimal temperatures for hibernation? // Comp. Biochem. Physiol. A. Physiol. 1991. Vol. 99. P. 323-326.

Perry, $R$. W. A review of factors affecting cave climates for hibernating bats in temperate North America // Environmental Reviews. 2013. Vol. 21 (1). P. 28-39.

Piasecki, J., Kwiatkowski, J. Mikroklimat Jaskini Niedźwiedziej w Kletnie // Jaskinia Niedźwiedzia w Kletnie, Ossolineum. Wrocław, 1989. P. 221-240.

Polonius, A. Ocena możliwości zabezpieczenia Jaskini ,,szachownica I” w rezerwacie „Szachownica” na podstawie przesłanek geomorfologiczno-geologicznych / Zakład Usług Badawczo-Rozwojowych „RERRA INCOGNITA”. Katowice, 2001. P. 1-32. (Manuscript).

Postawa, T. A cave microclimate as modelled by external climatic conditions and its effect on a hibernating bat assemblage: a case of the Jaskinia pod Sokolą Górą Cave // Proceedings of VIIIth EBRS / B. W. Wołoszyn (ed.). Publication of CIC ISEZ PAN. 2000. Vol. 1. P. 223-242.

Uhrin, M., Benda, P., Obuch, J., Urban, P. Changes in abundance of hibernating bats in central Slovakia (1992-2009) // Biologia. 2010. Vol. 65. P. 349-361.

Wojtaszyn, G., Rutkowski, T., Stephan, W., Kozirog, L. Urban drainage systems as important bat hibernacula in Poland // Fragmenta Faunistica. 2013. Vol. 56 (1). 83-88.

Wojtaszyn, G., Ignaczak, M., Jaros, R., Manias, J. Najdłuższy przelot nocka Natterera Myotis nattereri (Kuhl, 1817) z kolonii rozrodczej na zimowiska // Nietoperze. 2010. Vol. 9. P. 85-86.

Wotoszyn, B.W. Pliocene and Pleistocene bats of Poland // Acta Palaeontologica Polonica. 1988. Vol. 32. P. 207-325.

Van der Meij T., Van Strien A. J., Haysom K. A. et al. Return of the bats? A prototype indicator of trends in European bat populations in underground hibernacula // Mamm. Biol. 2015. Vol. 80. P. 170-177. 